\title{
Structure and function of antimicrobial peptide penaeidin-5 from the black tiger shrimp Penaeus monodon
}

\author{
Shao-Yang $\mathrm{Hu}^{\mathrm{a}, 1}$, Jan-Hsiung Huang ${ }^{\mathrm{b}, 1}$, Wei-Ting Huang ${ }^{\mathrm{a}}$, Yang-Hui Yeh ${ }^{\mathrm{a}}$, \\ Mark Hung-Chih Chen ${ }^{c}$, Hong-Yi Gong ${ }^{a}$, Tze-Ting Chiou ${ }^{d}$, Tzu-Hsuan Yang ${ }^{b}$, \\ Thomas T. Chen ${ }^{\text {e }}$, Jenn-Khan $\mathrm{Lu}^{\mathrm{d}, *}$, Jen-Leih $\mathrm{Wu}^{\mathrm{a}, *}$ \\ ${ }^{a}$ Institute of Cellular and Organismic Biology, Academia Sinica, Nankang, Taipei 115, Taiwan \\ ${ }^{\mathrm{b}}$ Institute of Microbiology and Biochemistry, National Taiwan University, Taipei 106, Taiwan \\ ${ }^{\mathrm{c}}$ Department of Biotechnology, Hung Kuang University, Taichung, Taiwan \\ d Department of Aquaculture, National Taiwan Ocean University, Keelung 202, Taiwan \\ e Department of Molecular and Cell Biology, University of Connecticut, Storrs, CT 06269, U.S.A.
}

Received 2 April 2006; accepted 12 June 2006

\begin{abstract}
The gene for penaeidin-5, an antimicrobial peptide comprising 55 amino acids, was isolated from the hemocyte of black tiger shrimp (Penaeus monodon). RT-PCR expression tests revealed that penaeidin-5 was produced in hemocytes, gills, the intestine and muscle. Western blot analysis confirmed the panaeidin-5 was aboundantin hemocytes, the intestine and hemolymph. Immunohistochemistry revealedpenaeidin-5 in the cuticle and gills that are considered primary defense barriers. The deduced amino acid sequence of penaeidin-5 included a proline-rich $\mathrm{N}$-terminal domain and a carboxyl-domain that contained six cysteine residues. Circular dichrosim analysis revealed an $\alpha$-helix in its secondary structure and the predicted 3D structure indicated twodisulfide bridges in the $\alpha$-helix. Based on the sequence of penaeidin- 5 peptide cDNA, synthetic penaeidin- 5 was prepared to carry out functional tests. The synthetic peptide had efficient bacteriostatic and bactericidal activity against Aerococcus viridans, and also inhibited the growth of two filamentous fungi, Fusarium pisi and Fusarium oxysporum. To measure penaeidin-5 in vivo, black tiger shrimp were challenged with Vibrio alginolyticus and A. viridans. At $3 \mathrm{~h}$ post-challenge, penaeidin-5 was induced and bacterial numbers decreased significantly by $12 \mathrm{~h}$ and $24 \mathrm{~h}$.
\end{abstract}

(C) 2006 Elsevier B.V. All rights reserved.

Keywords: Penaeus monodon; Antimicrobial peptides; Penseidins; Innate immunity

\footnotetext{
* Corresponding authors. Wu is to be contacted at Laboratory of Marine Molecular/Biology and Biotechnology 301, Institute of Cellular and Organismic Biology, Academia Sinica 128, Academia Road, Section 2, Nankang, Taipei 115, Taiwan. Tel.: +886 2 27899568; fax: +8862 27824595. Lu, Department of Aquaculture, National Taiwan Ocean, 2 Pei-Ning Rd. Keeling 202, Taiwan. Tel.: +8862 24622192x5236; fax: +886224631663.

E-mail addresses: F0008@mail.ntou.edu.tw (J.-K. Lu), jlwu@gate.sinica.edu.tw (J.-L. Wu).

${ }^{1}$ These authors contributed equally in this work.
}

\section{Introduction}

Antimicrobial peptides (AMPs) are considered to be key component of the innate immune system and they are widespread throughout the animal and plant kingdoms. Since the discovery of the first AMP cecropin from diapausing pupae of the lepidopteran Hyalophola cecropia (Boman and Hultmark, 1987), many AMPs have been identified and characterized from a wide 
variety of vertebrate and invertebrate species (Hertru et al., 1994). Based on amino acids sequences, structural features and functional features, AMPs have been divided into distinct subgroups with antimicrobial activities predominantly against particular pathogens (Bulet et al., 1999). Thus, more and more AMPs are being studied as potential therapeutic agents for aquaculture, agriculture and human medicine.

Penaeid shrimp are economically important aquaculture species. However, the production of shrimp was threatened by disease problems that may results in huge economic losses. Bacteria and fungi diseases may cause severe mortalities during the larval stages of shrimps and other crustaceans. For example, septicemia by the Gram-positive bacterium Aerococcus viridans can cause mortality in lobsters and crabs (Newman and Feng, 1982), and Gram-negative bacteria in the family Vibrionaceae, and fungi Fusarium spp. can cause mortality in shrimp (Song et al., 1993; Burns et al., 1979). To overcome such problems while also avoiding use of antibiotics, natural AMPs from shrimp have been considered. Penaeidins are AMPs that were first isolated from the plasma and hemocytes of Penaeus vannamei. The first three were named penaeidin-1, -2 and -3 , and their structures and antimicrobial activities were studied using recombinant proteins (Destoumieux et al., 1997). Later, the peptide penaeidin-4 was identified from Litopenaeus vannamei and characterized for structure and spectrum of activity using a synthetic preparation (Cuthbertson et al., 2002, 2004). A number of penaeidins have been identified and sequenced from a variety of penaeid shrimp species and common penaeidin signatures have been established based on amino acid sequences (Gueguen et al., 2006). Recently, penaeidin-5 cDNA was cloned from the hemocytes of the Penaeus monodon, as a full-length gene of $683 \mathrm{bp}$ with an open reading frame of 222 bp encoding a deduced peptide of 74 amino acids. This peptide includes a conserved leader sequence of 19 amino acids and a putative mature peptide of 55 amino acids (Chen et al., 2004). The mature peptide contains a proline-rich domain at the $\mathrm{N}$-terminus and six cysteine residues at $\mathrm{C}$-terminus. Although the structure of penaeidin-5 contains overall features characteristic of penaeidins as described in Destoumieux et al. (1997). However, comparison with other mature penaeidins of L. vannamei revealed less than $50 \%$ amino acid sequence identity and features that made it quite unique among AMP families. Thus, we considered that further research on the antimicrobial activity of penaeidin-5 was worthwhile, especially with respect to pathogens of shrimp and other crustaceans.

\section{Materials and methods}

\subsection{Animals}

Juveniles from the black tiger shrimp, P. monodon, were obtained from different hatcheries of the Ilan, Taiwan. The average of body length and body weight of the adult shrimps were approximately $18.1 \pm 2.2 \mathrm{~cm}$ and $43.3 \pm$ $3.4 \mathrm{~g}$, respectively. These shrimps were maintained in one ton tanks equipped with circulating seawater at $28{ }^{\circ} \mathrm{C}$.

\subsection{Semi-quantitative RT-PCR and Western blotting}

Total RNA was isolated from the various tissues using TRIZOL reagent (Boehringer Mannheim), according to the manufacturer's instructions. First-strand cDNA was synthesized in a $20 \mu 1 \mathrm{RT}$ reaction from $250 \mathrm{ng}$ of total RNA, using SuperScriptIII one-step RT-PCR (Invitrogen). The mRNA for the ubiquitous expression $\beta$-actin was used for normalization. The primers used in this study were as follows: penaeidin-5 forward primer 5'ACC AGT CGG TGC TTG GCT CT, penaeidin-5 reverse primer 5'-GAG TAG TAC AAT TCC GAA TGT $\mathrm{CC}, \beta$-actin forward primer $5^{\prime}$-CTT GTG GTT GAC AAT GGC TCC G and $\beta$-actin reverse primer 5'-TGG TGA AGG AGT AGC CAC GCT C. The first PCR cycles were: $94^{\circ} \mathrm{C}$, for 2 min flowed by 35 cycles at $94^{\circ} \mathrm{C}$ for $30 \mathrm{~s}, 55^{\circ} \mathrm{C}$ for $30 \mathrm{~s}, 72^{\circ} \mathrm{C}$ for $30 \mathrm{~s}$ and a final cycle at $72{ }^{\circ} \mathrm{C}$ for $7 \mathrm{~min}$. To perform the Western blot analysis, proteins from various tissues were extracted in homogenizing buffer (Tris-HCl $13.7 \mathrm{mM}, \mathrm{Na}_{2}$ EDTA $20 \mathrm{mM}$, sucrose $25 \mathrm{mM}, 9.6 \mathrm{mM}, \mathrm{pH}$ 7.4). The soluble proteins were separated by $10 \%$ Tricine SDS-PAGE and transferred to a nitrocellulose membrane using a Trans-Blot SD Semi-Dry Transfer Cell (Bio-Rad). The membrane was blocked by the NET buffer $(0.25 \%$ gelatin, $50 \mathrm{mM}$ $\mathrm{NaCl}, 0.05 \%$ Tween, $50 \mathrm{mM}$ Tris-HCl, 5 mM EDTA, $\mathrm{pH}$ 7.5) at $4{ }^{\circ} \mathrm{C}$ overnight, and then incubated for $1 \mathrm{~h}$ with the penaeidin-5 polyclonal antibody (Genesis Biotech Inc.). After a $1 \mathrm{~h}$ incubation, the membrane was washed three times using PBS buffer containing $0.05 \%$ Tween 20 and then incubated with 1:7500 dilution of alkaline phosphatase conjugated anti-rat antibody. The membrane was washed and the location of the penaeidin-5 was detected using an ECL kit, according to the manufacturer's protocol (Amersham). The protein for the ubiquitous translation $\beta$-actin was used for internal normalization.

\subsection{Immunohistochemistry (IHC)}

Gill and cuticular tissues from black tiger shrimp were washed in the PBS buffer $(140 \mathrm{mM} \mathrm{NaCl}, 2.7 \mathrm{mM}$ 
Table 1

Synthetic antimicrobial peptides and microbial strains used in susceptibility tests

\begin{tabular}{lll}
\hline Peptide & Amino acid sequences & Organism source \\
\hline Penaeidin-5 & QGYQGGYTRPFPRPPYGGGYHPVPVCTSCHRLSPLQARACCRQLGRCCDAKQTYG & Penaeus monodon \\
Cecropin A & K W K L F K K I E K V G Q N I R D G I I K A G P A V A V V G Q A T Q I A K & Hyalophora cecropia \\
$\begin{array}{l}\text { Cecropin B } \\
\text { Magainin }\end{array}$ & K W K V F K K I E K M G R N I R N G I V K A G P I A V L G E A K A L G & Hyalophora ceropia \\
& GIGKFLHSAKKFGKAFVGEIMNS & Xenopus laevis \\
Strain & Culture medium & Source \\
Aerococcus viridan & Blood TBS (tryptic soy broth $+5 \%$ fetal bovine serum) & BCRC 14925 \\
Fusarium pisi & Potato dextrose broth & BCRC 35290 \\
Fusarium oxysporum & Potato dextrose broth & BCRC 35100 \\
\hline
\end{tabular}

a BCRC: Bioresources Collection and Research Center, Hsinshu, Taiwan.

$\mathrm{KCl}, 10 \mathrm{mM} \mathrm{Na} \mathrm{HPO}_{4} \cdot 12 \mathrm{H}_{2} \mathrm{O}, 1.8 \mathrm{mM} \mathrm{K \textrm {K } _ { 2 }} \mathrm{PO}_{4}, \mathrm{pH}$ 7.3) and then fixed in a solution containing $4 \%$ paraformaldehyde (PFA). After dehydration, the tissues were embedded in agarose and $8 \mu \mathrm{m}$ sections were cut, mounted on poly-L-lysine coated slides, and stored at $4{ }^{\circ} \mathrm{C}$ until used. Immunohistochemistry of penaeidin-5 in gill and cuticular tissues was performed according to the previously developed protocol. Immunoreactions of the sections were carried out using polyclonal antibodies specific $P$. monodon penaeidin-5. This product was washed and incubated with 1:1000 dilution of horseradish peroxidase (HRP)-conjugated anti-rat antibody (Bethyl). DAB substrate solution was used in the immunodetection according to manufacturer's protocol (Amersco). Controls consisted in pre-absorbing the antibody overnight at $4{ }^{\circ} \mathrm{C}$ with synthetic penaeidin-5 (10 $\mu \mathrm{g}$ peptide/ $\mu \mathrm{g}$ purified $\mathrm{IgG}$ ).

\subsection{Circular dichroism analysis and $3 D$ modeling}

Penaeidin-5 molecular ellipticity was measured under far-UV using a Jasco J-720 spectropolarimeter. The peptide was dissolved in distilled water to a final concentration of $0.2 \mu \mathrm{g} / \mu \mathrm{l}$, and then analyzed at a resolution of $0.05 \mathrm{~nm}$, from $260 \mathrm{~nm}$ to $280 \mathrm{~nm}$, by ultraviolet spectroscopy using a cell of $0.1 \mathrm{~cm}$ path length. The three-dimensional structure of penaeidin-5 was predicted by using the MODELLER program and drawn with the program RasMol version 2.6.

\subsection{In vitro susceptibility test}

Antimicrobial activity assays were modified from the bacteriostatic and bactericidal assays previously described (Chiou et al., 2005). The pathogens, growth medium and antimicrobial peptides used are shown in Table 1 using published peptide sequences, the antimicrobial peptides, cecropin $\mathrm{A}$ and $\mathrm{B}$, magainin-II and penaeidin-5 were chemically synthesized by Genemed Synthesis Inc. (South San Francisco, CA). The purity of these antimicrobial peptides was $>90 \%$ by HPLC analysis. The antibiotic tetracycline was used as positive control. They were dissolved in a PBS buffer for activity assays. Three different bacteria, Aerococcus viridans, Fusarium pisi and Fusarium oxysporum were used as models for the bacteriostatic and bactericidal/fungicidal assays. A single colony was picked up and inoculated into a $250 \mathrm{ml}$ flask containing $50 \mathrm{ml}$ of appropriate culture medium in a shaking incubator at $30^{\circ} \mathrm{C}$ at $150 \mathrm{rpm}$. After $24 \mathrm{~h}$ cultivation, cell pellets were isolated by centrifugation at $3000 \times g$ for $15 \mathrm{~min}$ at $4{ }^{\circ} \mathrm{C}$ and washed twice in the PBS buffer. To obtain uniform (standard) cell concentrations, the washed cell pellets were re-suspended thoroughly in PBS buffer and the suspension was adjusted to an optical density (OD) of 1 at $540 \mathrm{~nm}$. Subsequently, $10 \mathrm{ml}$ of OD 1 suspension was diluted with $90 \mathrm{ml}$ of appropriate culture medium (total $100 \mathrm{ml}$ ) to prepare the stock susceptibility test broth that was dispensed in $1.9 \mathrm{ml}$ aliquots into $10 \mathrm{ml}$ sterile assay tubes for activity assays.

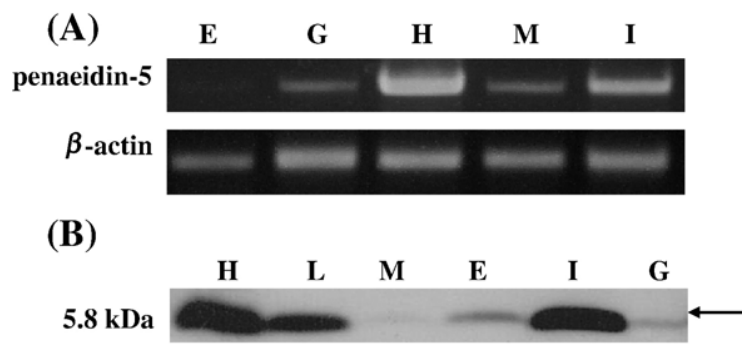

Fig. 1. Tissue expression profile of penaeidin-5 gene. (A) Reverse transcriptase-polymerase chain reaction (RT-PCR) was analyzed for expression of penaeidin-5 gene. The ubiquitously expressed gene $\beta$ actin was used for normalization. (B) Western blot analysis of penaeidin-5 expression. Arrow indicated the native form of penaeidin5. Lane E, eye; G, Gill; H, haemocyte; M, muscle; I, intestine; L, lymph. 
(A)

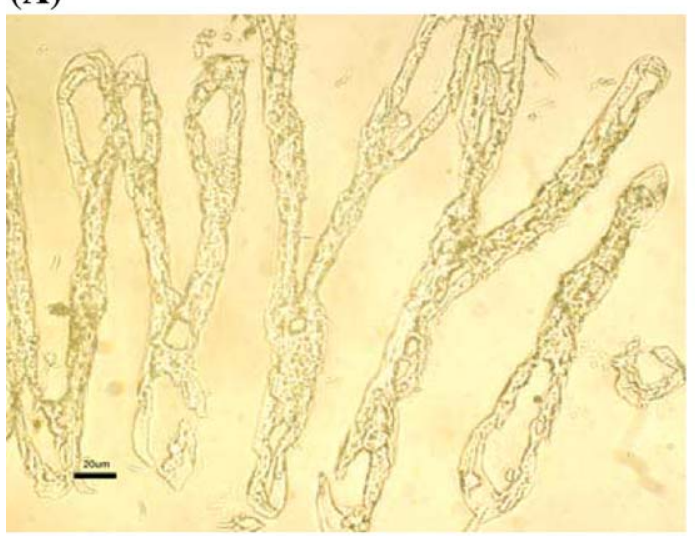

(C)

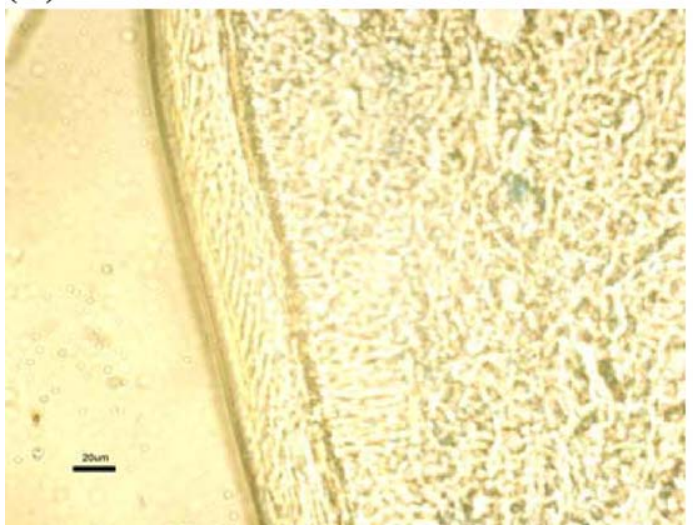

(B)

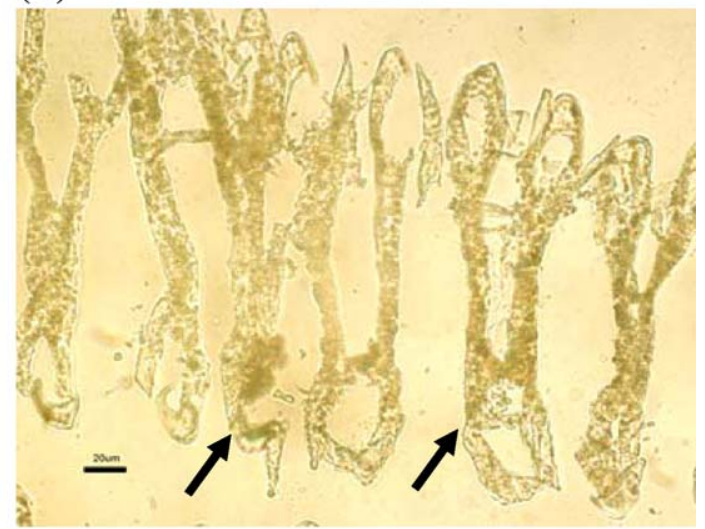

(D)

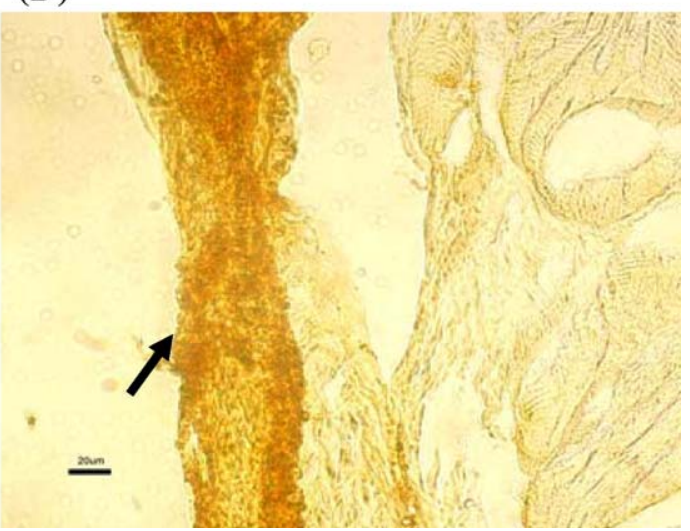

Fig. 2. Detection of penaeidin-5 in tiger shrimp tissue by immunohistochemistry analysis in the gill and carapace. (A) Negative control for haemocytes located in gill blood vessels. (B) Positive signals in the gill. The arrow shows haemocytes located in the gill blood vessels. (C) Negative control for cuticular epithelium in the carapace. (D) Positive signals in the carapace. The arrow indicates the area of positive reaction in the subcuticular epithelium of the carapace. Bars $=20 \mu \mathrm{m}$. Magnification, $600 \times$.

To these assay tubes, $0.1 \mathrm{ml}$ of serial dilutions of synthetic antimicrobial peptide solutions were added prior to cultivation on a shaking incubator at $30{ }^{\circ} \mathrm{C}$ at $150 \mathrm{rpm}$ for $16 \mathrm{~h}$. The minimal inhibitory concentration (MIC) was expressed as the lowest concentration that inhibited bacterial growth. To determine bactericidal activity of antimicrobial peptides, $100 \mu \mathrm{l}$ aliquots of test broths from the MIC test were spread on either Blood TSB (for bacteria) or potato dextrose agar plate (for filamentous fungi) and incubated at $30{ }^{\circ} \mathrm{C}$ for $24 \mathrm{~h}$ and $48 \mathrm{~h}$, respectively. The minimum bactericidal concentration (MBC) and minimum fungicidal concentration (MFC) were expressed as the minimum concentration at which there was no colony formation.

\subsection{In vivo pathogen challenge tests}

The marine bacterium Vibrio alginolyticus (SY4), a well-known shrimp pathogen was purchased from the

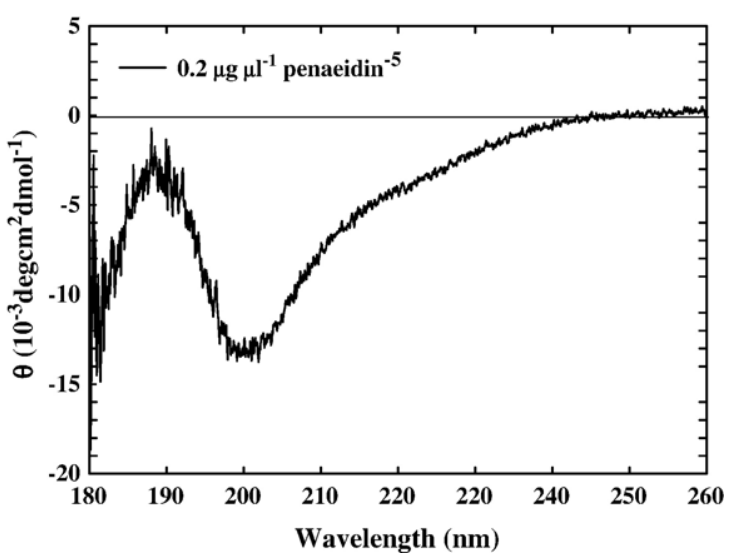

Fig. 3. Structural stability of penaeidin-5. Circular dichroism analysis of penaeidin- 5 in distilled water was done at $25{ }^{\circ} \mathrm{C}$. The data indicate an $\alpha$-helix structure around $200 \mathrm{~nm}$ while the lower wave length at $190 \mathrm{~nm}$ implies a strong contribution of random coils or loops constrained by disulfides. 
American Type Culture Collection (ATCC, Manassas, Va.). A single colony of either $V$. alginolyticus or $A$. viridans was pick up and inoculated into a $250 \mathrm{ml}$ flask containing $50 \mathrm{ml} \mathrm{TSB}$ broth (tryptic soy broth $30 \mathrm{~g} \mathrm{l}^{-1}$, $\mathrm{NaCl} 15 \mathrm{~g} \mathrm{l}^{-1}$ ) or Blood TSB broth, respectively, in a shaking incubator at $30{ }^{\circ} \mathrm{C}$ at $150 \mathrm{rpm}$. After overnight cultivation, the culture broth was centrifuged at $3000 \times g$ for $15 \mathrm{~min}$ at $4{ }^{\circ} \mathrm{C}$ to isolated the cell pellets. The pellets were washed twice and re-suspended thoroughly in sterile PBS buffer before adjustment to cell concentrations of $1.2 \times 10^{5} \mathrm{CFU} / \mathrm{ml}$ of $V$. alginolyticus and $10^{8} \mathrm{CFU} / \mathrm{ml}$ of $A$. viridans. The juveniles black tiger shrimp was used for these challenge tests. Thirty black tiger shrimps were divided into two groups and each group was injected $100 \mu \mathrm{l}$ of pathogen solution (104 CFU of $V$. alginolyticus per shrimp; $10^{7} \mathrm{CFU}$ of A. viridans per shrimp) into the muscle between third and fourth somite. The shrimp were then replaced in the cultural tanks for continued incubation. At various intervals thereafter, $5 \mu \mathrm{l}$ samples of hemolymph were withdrawn from individual shrimp and mixed with an equal volume of anti-coagulant $(27 \mathrm{mM}$ sodium citrate, $336 \mathrm{mM} \mathrm{NaCl}, 115 \mathrm{mM}$ glucose, 9 mM EDTA, $\mathrm{pH}$ 7.0) to prevent the hemocytes from coagulated. A $5 \mu 1$ of mixture hemocytes solution from $V$. alginolyticus and A. viridans injected shrimps were inoculated into $3 \mathrm{ml}$ of TSB and Blood TSB broth, respectively, and cultured at $30{ }^{\circ} \mathrm{C}$ at $150 \mathrm{rpm}$ for $16 \mathrm{~h}$. A $100 \mu \mathrm{l}$ of cultured broth was spread on the TSB and Blood TSB agar plate and incubated at $30{ }^{\circ} \mathrm{C}$ for $24 \mathrm{~h}$, respectively. The experiment was performed triplicate. The variation of bacterial colony-forming units was used to evaluate the response of endogenous penaeidin-5.

\section{Results}

\subsection{Tissue distribution of penaeidin-5 $\mathrm{mRNA}$}

To investigate the tissue expression of penaeidin-5, the penaeidin- 5 transcripts with a size of $400 \mathrm{bp}$ was carried out with semi-quantitative RT-PCR in different tissues. The expression of penaeidin- 5 was abundant in hemocytes and the intestine and intermediate in the gill and muscle. There was no signal in the eyes (Fig. 1A). The expression pattern of penaeidin-5 was also investigated by Western blotting using the penaeidin- 5 polyclonal antibody. Mature penaeidin-5 could be recognized at $5.8 \mathrm{kDa}$, which agree with the expected molecular weight of the penaeidin-5 cDNA. Corresponding with the mRNA expression level, penaeidin-5 was found abundantly in hemocytes, the intestine and hemolymph (Fig. 1B). Based on the above results, penaeidin-5 existed mainly in the hemocytes. As shrimp gills are well known to be intensely vascularised, penaeidin-5 in gills was further confirmed by immunohistochemistry. The hemocytes only reacted with penaeidin-5 antibody and were located exclusively in the gill vessels (Fig. 2B); no positive reaction could be seen in the control (Fig. 2A). Furthermore, the subcuticular tissue was also investigated since it is involved in the first line of defense against pathogen. In comparison with the control, significant penaeidin-5
(A)

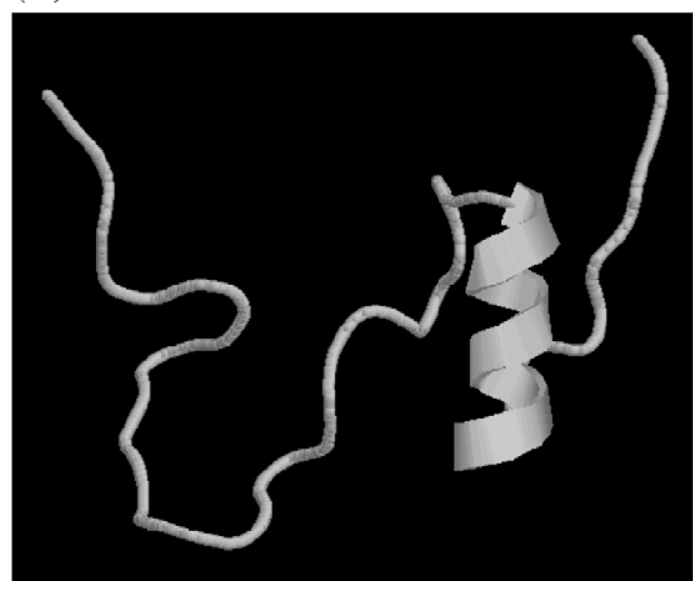

(B)

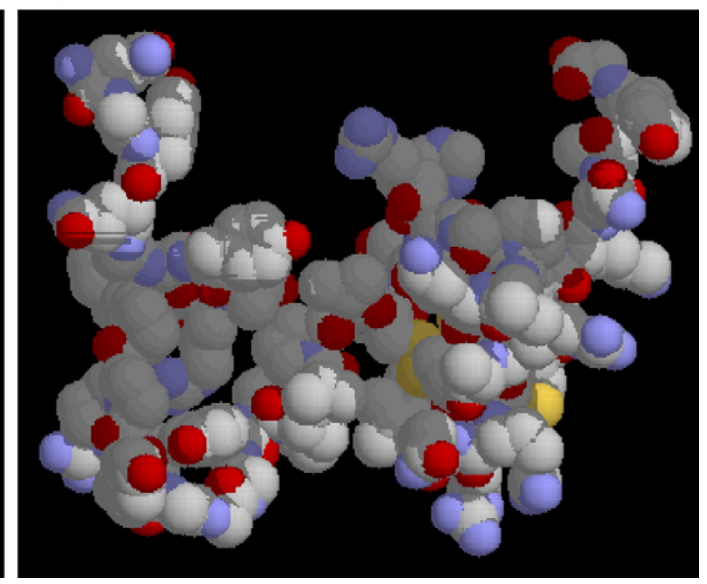

Fig. 4. Pedicted three-dimensional structure of penaeidin-5. (A) The structure of the full-length peptide was prepared using MODELLER and shows a CS $\alpha \beta$-type $\alpha$-helix structure in the carboxy-terminal region. (B) Clustering of cationic and hydrophobic amino acids. Red, basic (positively charged) amino acids; blue, hydrophobic amino acids; yellow, $\alpha$-helix. Other amino acids are shown in gray. 
labeling could be detected in sub-cuticular epithelium of the shrimp (Fig. 2C,D).

\subsection{Circular dichroism and three-dimensional structure of the synthetic penaeidin-5}

The proline-rich domain and cysteine-rich cyclic domain of penaeidins are unique features among antimicrobial peptides. In penaeidin-5, the linear prolinerich domain, which contains the triple Pro-Arg-Pro motif, consists of six proline residues at the $\mathrm{N}$-terminal region while the cysteine-rich cyclic domain is located at the carboxy-terminal region. Circular dichroism analysis revealed a minimum signal of around $200 \mathrm{~nm}$ is indicative of a $\alpha$-helix structure while a lower wavelength of $190 \mathrm{~nm}$ implied a strong contribution of poorly ordered structures that could possibly be random coils or loops (Fig. 3). A three-dimensional helical structure that contained two disulfide bridges was predicated by MODELLER. The helix structure was similar to the CS $\alpha \beta$-type antimicrobial peptides that contain a single $\alpha$-helix and a pair of antiparallel $\beta$ sheets stabilized by multi-intramolecular disulfide bridges (Fig. 4). Because the $\mathrm{CS} \alpha \beta$-type peptides possess antimicrobial activity against a wide spectrum of pathogens, the synthetic penaeidin-5 peptides was testes for bacteriostatic and bactericidal or/and fungicidal activity.

\subsection{In vitro susceptibility test}

The bacteriostatic and bactericidal or fungicidal activity of the antimicrobial peptides is shown in Table 2 . Penaeidin-5 had strong antimicrobial activity against $A$. viridans. The minimum inhibitory and bactericidal concentrations were $\mu \mathrm{M}$ and $150 \mu \mathrm{M}$, respectively. In comparison to antibiotics and antimicrobial peptides in other species, penaeidin-5 had the lowest minimum

Table 2

Effect of penaeidin-5 and other species of antimicrobial peptides on aquaculture pathogens

\begin{tabular}{|c|c|c|c|c|c|c|}
\hline & \multicolumn{2}{|c|}{$\begin{array}{l}\text { Aerococcus } \\
\text { viridans }\end{array}$} & \multicolumn{2}{|c|}{ Fusarium pisi } & \multicolumn{2}{|c|}{$\begin{array}{l}\text { Fusarium } \\
\text { oxysporum }\end{array}$} \\
\hline & $\begin{array}{l}\text { MIC } \\
(\mu \mathrm{M})\end{array}$ & $\begin{array}{l}\mathrm{MBC} \\
(\mu \mathrm{M})\end{array}$ & $\begin{array}{l}\text { MIC } \\
(\mu \mathrm{M})\end{array}$ & $\begin{array}{l}\text { MBC } \\
(\mu \mathrm{M})\end{array}$ & $\begin{array}{l}\text { MIC } \\
(\mu \mathrm{M})\end{array}$ & $\begin{array}{l}\text { MBC } \\
(\mu \mathrm{M})\end{array}$ \\
\hline Penaeiden-5 & 20 & 150 & 5 & 20 & 10 & 20 \\
\hline Cecropin A & 200 & $>500$ & 100 & 150 & 75 & 150 \\
\hline Cecropin B & 30 & 400 & 20 & 30 & 10 & 20 \\
\hline Magainin II & 1 & 5 & 1 & 1 & 1 & \\
\hline Tetracycline & 1 & 300 & 300 & $>500$ & 500 & $>500$ \\
\hline
\end{tabular}

Values represent means of three experiments.

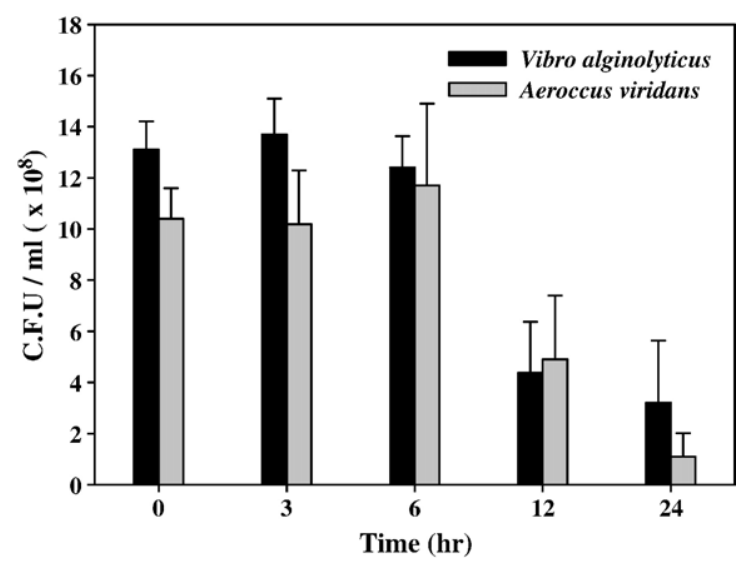

Fig. 5. In vivo pathogen challenge test. The immunoresponse of penaeidin-5 in black tiger shrimp after injection of Vibrio alginolyticus and Aerococcus viridians was in terms of bacterial colonyforming units as described in Section 2. The bacterial number is shown as mean \pm S.D. $(n=6)$. The bacterial number for $V$. alginolyticus and $A$. viridians at $12 \mathrm{~h}$ and $24 \mathrm{~h}$ were significantly different $(P<0.05)$.

bactericidal concentrations. In the fungi, the penaeidin-5 also showed a significant antimicrobial activity against $F$. pisi and F. oxysporum. Only $20 \mu \mathrm{M}$ was required for fungicidal activity.

\subsection{In vivo pathogen challenge test}

In general, no large variation occurred in the bacterial number $6 \mathrm{~h}$ after $V$. alginolyticus or A. viridans were injected (Fig. 5). However, the bacterial number was decreased significantly form $1.22 \times 10^{9} \mathrm{CFU} / \mathrm{ml}$ at $6 \mathrm{~h}$ to $4.37 \times 10^{8} \mathrm{CFU} / \mathrm{ml}$ at $12 \mathrm{~h}$ and $3.21 \times 10^{8} \mathrm{CFU} / \mathrm{ml}$ at $24 \mathrm{~h}$ in the $V$. alginolyticus injected samples (Fig. 5A). In the $A$. viridans injected samples, similar results were obtained. The bacterial number was decreased significantly from $1.23 \times 10^{9} \mathrm{CFU} / \mathrm{ml}$ at $6 \mathrm{~h}$ to $4.9 \times 10^{8} \mathrm{CFU} /$

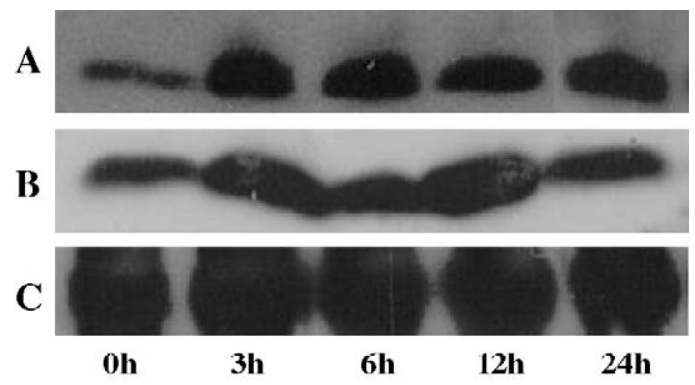

Fig. 6. The expression of penaeidin-5 at different times post pathogen injection was performed by Western blotting. (A) The time expression profile of penaeidin-5 with Vibrio alginolyticus. (B) The time expression profile of penaeidin-5 Aerococcus viridians. (C) The ubiquitous expression of $\beta$-actin as an internal control. 
$\mathrm{ml}$ at $12 \mathrm{~h}$ and $1.1 \times 10^{8} \mathrm{CFU} / \mathrm{ml}$ at $24 \mathrm{~h}$ (Fig. 5B). We assumed that the decrease in bacteria in the pathogen injected shrimp was due, at least in part, to the induction of penaeidin-5. Therefore, we evaluated the expression of penaeidin- 5 in the hemocytes of pathogen injected shrimp by Western blotting using ubiquitously expressed $\beta$-actin as an internal control. We found that expression level of penaeidin-5 was induced within $3 \mathrm{~h}$ after $V$. alginolyticus or $A$. viridans injection and that a higher protein level of penaeidin- 5 was maintained up to $24 \mathrm{~h}$ (Fig. 6). Hence, we proposed that injection of the pathogens triggers production of penaeidin- 5 .

\section{Discussion}

Antimicrobial peptides have been established as key players in animal defense systems. The mature penaeidin5 cDNA, which encode a $5.8 \mathrm{kDa}$ antimicrobial peptide, was first cloned from the black tiger shrimp P. monodon. In a previous report, penaeidins from $L$. vannamei were demonstrated to be constitutively synthesized and stored in shrimp hemocytes where their mRNA expression level was highest (Destoumieux et al., 2000a,b). A similar result was seen in our experiments with high levels of expression in hemocytes and the intestine. The high level of penaeidin-5 expression gills probably resulted because they are intensively vascularised.

Some antimicrobial peptides from the crustacean have chitin-binding activity because of the cysteine-rich region in their $\mathrm{COOH}$-terminal domain. This property is considered essential not only for antimicrobial activity, but also for chitin assembly in wound healing. Thus, it may also play an important role in preventing invasive infections (Destoumieux et al., 2000a,b). Penaeidin-5 displayed a similar motif in its $\mathrm{COOH}$-terminal domain. Thus, we suppose that the penaeidin- 5 also has chitinbinding properties that are involved in resistance to infections. Many reports indicate that specific structures of antimicrobial peptides have bactericidal activity against specific pathogens. A structural feature of the penaeidin family is that the mature peptides including an $\mathrm{N}$-terminal cyclisation (Bachère et al., 2000). In our circular dichroism analysis, the lower wavelength of $190 \mathrm{~nm}$ implies a coil or loop structure. Thus, we assumed that it contains an N-terminal cyclisation as do other penaeidins. Comparing the results from circular dichroism with those from 3D structural modeling, we can expect that that an $\alpha$ helix structure existed in the C-terminus of penaeidin-5. It contains six cysteine residues that are probably engaged in the formation of three intramolecular disulfide bridges that contribute to the formation of the $\alpha$-helix structure. The helix structure was similar to that of CS $\alpha \beta$-type antimicrobial peptides such as drosomycin. It is noteworthy that the $C S \alpha \beta$ motif antimicrobial peptides are effective against a wide variety of microbes such as Gramnegative bacteria, Gram-positive bacteria and yeasts. Therefore, some of the peptides from this family are being developed as drugs base on their specific antimicrobial features (Landon et al., 1997).

Comparison of penaeidin-5 with other penaeidins, the MIC concentration of penaeidin-2 and penaeidin-3 for Fusarium spp. was around $5 \mu \mathrm{M}-10 \mu \mathrm{M}$; thus, the bacteriostatic activity of penaeidin-5 was similar to penaeidin-2 and penaeidin-3 (Destoumieux et al., 1999). In addition to other penaeidins, the antimicrobial peptides from other species also used to compare the antimicrobial activity. Cecropin A and B are a well-characterized family of antimicrobial peptides from the Hyalophora cecropia. They show a very broad spectrum of activities against Gram-positive and Gram-negative bacteria, also having antifungal activities such as Fusarium spp. and Aspergillus spp. (Boman, 1995; De Lucca et al., 1998). Magainin-II is a natural antibiotic from frog skins with significant activity against the bacteria, fungi, protozoa, parasites and even viruses (Guerrero et al., 2004; Chinchar et al., 2004). We found that penaeidin-5, as well as cecropin A, cecropin B and magainin-II, were efficient bacteriostatic and bactericidal or/and fundicidal agents. The antimicrobial activity of penaeidin-5 was more efficient when compared with cecropin A and cecropin B. Since tetracycline is an antibacterial antibiotic, a high amount is necessary to act against fungi such as Fusarium spp. By contrast antimicrobial peptides like penaeidin-5 are much more effective against fungi. Based on the characteristic of penaeidin-5, we recently developed a recombinant penaeidin- 5 as a fodder additive to enhance the immunity of marine animals. We are also developing transgenic shrimp that over-express penaeidin- 5 in the hope that can be used as broodstock for the shrimp aquaculture industry.

\section{Acknowledgements}

This work was supported by grants from the National Science Council NSC 91-2317-B-001-021-, NSC 922317-B-001-035-, NSC 94-2317-B-001-006- and Nugen Bioscience Co. Ltd.

\section{References}

Bachère, E., Destoumieux, D., Bulet, P., 2000. Penaeidins, antimicrobial peptides of shrimp: a comparison with other effectors of innate immunity. Aquaculture 191, 71-88.

Boman, H.G., 1995. Peptide antibiotics and their role in innate immunity. Annu. Rev. Immunol. 13, 61-92. 
Boman, H.G., Hultmark, D., 1987. Cell-free immunity in insects. Annu. Rev. Microbiol. 41, 103-126.

Bulet, P., Hetru, C., Dimarcq, J.L., Hoffmann, D., 1999. Antimicrobial peptides in insects; structure and function. Dev. Comp. Immunol. 23, 329-344.

Burns, C.D., Berrigan, M.E., Henderson, G.E., 1979. Fusarium sp. infection in the freshwater prawn, Macrobrachium rosenbergii. Aquaculture 16, 193-198.

Chen, J.Y., Pan, C.Y., Kuo, C.M., 2004. Molecular cloning and sequencing of shrimp (Penaeus monodon) penaeidin-5 cDNA. Fish Shellfish Immunol. 16, 665-670.

Chinchar, V.G., Bryan, L., Silphadaung, U., Noga, E., Wade, D., Rollins-Smith, L., 2004. Inactivation of viruses infecting ectothermic animals by amphibian and piscine antimicrobial peptides. Virology 323, 268-275.

Chiou, T.T., Wu, J.L., Chen, T.T., Lu, J.K., 2005. Molecular cloning and characterization of cDNA of penaeidin-like antimicrobial peptide from tiger shrimp (Penaeus monodon). Mar. Biotechnol. 7, 119-127.

Cuthbertson, B.J., Shepard, E.F., Chapman, R.W., Gross, P.S., 2002. Diversity of the penaeidin antimicrobial peptides in two shrimp species. Immunogenetics 54, 442-445.

Cuthberson, B.J., Bullesbach, E.E., Fievet, J., Bachere, E., Gross, P.S., 2004. A new class (penaeidin class 4) of antimicrobial peptides from the Atlantic white shrimp (Litopenaeus setiferus) exhibits target specificity and independent proline-rich-domain function. Biochem. J. 381, 79-86.

De Lucca, A.J., Bland, J.M., Jacks, T.J., Grimm, C., Walsh, T.J., 1998. Fungicidal and binding properties of the natural peptides cecropin B and dermaseptin. Med. Mycol. 36, 291-298.

Destoumieux, D., Bulet, P., Loew, D., Van Doresselaer, A., Rodriguez, J., Bachère, E., 1997. Penaeidins: a new family of antimicrobial peptides in the shrimp, Penaeus vannamei (Decapoda). J. Biol. Chem. 272, 28398-28406.

Destoumieux, D., Bulet, P., Strub, J.M., Van Dorsselaer, A., Bachère, E., 1999. Recombinant expression and range of activity of penaeidins, antimicrobial peptides from penaeid shrimp. Eur. J. Biochem. 266, 335-346.

Destoumieux, D., Munoz, M., Bulet, P., Bachère, E., 2000a. Penaeidins, a family of antimicrobial peptide from the penaeid shrimp (Crustacea, Decapoda). Cell. Mol. Life Sci. 57, 1260-1271.

Destoumieux, D., Munoz, M., Cosseau, C., Rodriguez, J., Bulet, P., Comps, M., Bachere, E., 2000b. Penaeidins, antimicrobial peptides chitin-binding activity, are produced and stored in shrimp granulocytes and released after microbial challenge. J. Cell Sci. $113,461-496$.

Gueguen, Y., Garnier, J., Robert, L., Lefranc, M.P., Mougenot, I., de Lorgeril, J., Janech, M., Gross, P.S., Warr, G.W., Cuthbertson, B., Barracco, M.A., Bulet, P., Aumelas, A., Yang, Y., Bo, D., Xiang, J., Tassanakajon, A., Piquemal, D., Bachère, E., 2006. PenBase, the shrimp antimicrobial peptide penaeidin database: sequence-base classification and recommended nomenclature. Dev. Comp. Immunol. 30, 283-288

Guerrero, E., Saugar, J.M., Matsuzaki, K., Rivas, L., 2004. Role of positional hydrophobicity in the leishmanicidal activity of magainin-2. Antimicrob. Agents Chemother. 48, 2980-2986.

Hertru, C., Bulet, P., Cociancich, S., Dimarcq, J.L., Hoffmann, D., Hoffmann, J.A., 1994. Antibacterial peptides/polypeptides in the insect host defense: a comparison with vertebrate antimicrobial peptides/polypeptides. In: Hoffmann, J.A., Janeway, C.A., Natori, S. (Eds.), Phylogenetic Perspectives in Immunity: the Insect Host Defense. CRC Press, Inc., FL.

Landon, C., Sodano, P., Hetru, C., Hoffmann, J.A., Ptak, M., 1997. Solution structure of drosomycin, the first antifungal protein from insects. Protein Sci. 6, 1878-1884.

Newman, M.C., Feng, S.Y., 1982. Susceptibility and resistance of the rock crab, cancer irroratus, to natural and experimental bacterial infection. J. Invertebr. Pathol. 40, 75-88.

Song, Y.L., Cheng, W., Wang, C.H., 1993. Isolation and characterization of Vibrio damsela infectious for cultured shrimp in Taiwan. J. Invertebr. Pathol. 61, 24-31. 